\title{
Damage-Control Surgery for Maternal Near-Miss Cases of Placenta Previa and Placenta Accreta Spectrum
}

\author{
Abdulrahim A Rouzi (D) \\ Mohammed Sulaimani \\ Department of Obstetrics and \\ Gynecology, King Abdulaziz University, \\ Jeddah, Saudi Arabia
}

Purpose: There is paucity of reports on damage control surgery use in near-miss cases associated with placenta previa, and placenta accreta spectrum. The objective is to report the outcome of damage control surgery for the obstetrical hemorrhage in near-miss cases of placenta previa and placenta accreta spectrum.

Materials and Methods: The records of all women who had damage control surgery defined as abdominopelvic packing, followed by a period of medical stabilization in the intensive care unit for near-miss placenta previa and placenta accreta spectrum at King Abdulaziz University Hospital, Jeddah, Saudi Arabia, between November 1, 2007, and March 1, 2020, were identified and reviewed.

Results: During the study period, seven women met the inclusion criteria. There were three women with placenta previa, three women with placenta previa accreta, and one woman with placenta accreta. Five women had cesarean section followed by laparotomy, hysterectomy, and damage control surgery, one woman had a cesarean hysterectomy and damage control surgery, and one woman had hysterectomy and damage control surgery. Estimated "nearmiss" intraoperative bleeding ranged from 2 to 7 liters for the seven women (median $5 \mathrm{~L}$; IQR 3.5, 6), which was managed by massive blood transfusion. Complications included disseminated intravascular coagulation (3 women), intestinal obstruction (1 woman), acute renal failure (1 woman), and vesicovaginal fistula (1 woman). Hospital stay ranged from 8 to 44 days (median 37; IQR 21, 39).

Conclusion: Damage control surgery can be life-saving. It should be in the armamentarium of the health care providers managing women with placenta previa, and placenta accreta spectrum.

Keywords: damage control surgery, placenta previa, placenta accreta spectrum
Correspondence: Abdulrahim A Rouzi Department of Obstetrics and Gynecology, King Abdulaziz University, PO Box 80215, Jeddah, 21589, Saudi Arabia

Tel +966505602587

Email aarouzi@gmail.com

\section{Introduction}

Severe bleeding mostly postpartum hemorrhage ( $\mathrm{PPH})$ is the leading cause of maternal mortality worldwide. ${ }^{1}$ Placenta previa, and placenta accreta spectrum (PAS; formerly known as morbidly adherent placenta) are contributing factors. ${ }^{2,3}$ Placenta previa and PAS carry significant mortality and severe, life-threatening morbidity or "near-miss" circumstances in relation to their several complications in addition to $\mathrm{PPH} .{ }^{3,4}$ Maternal near miss is defined as a woman who nearly died but survived a complication that occurred during pregnancy, childbirth, or within 42 days of termination of a pregnancy. ${ }^{5}$ In such cases, damage control surgery defined as abdomino-pelvic packing, followed by a period of medical stabilization in the 
intensive care unit, can be life-saving. ${ }^{6}$ However, there is paucity of reports on its use in near-miss cases associated with placenta previa and PAS. Our objective is to report the outcomes of damage control surgery for obstetrical the hemorrhage in near-miss cases of placenta previa and PAS in our hospital.

\section{Materials and Methods}

This retrospective study of seven cases (case series) was conducted at King Abdulaziz University Hospital, Jeddah, Saudi Arabia. Women who had damage control surgery for "near-miss" placenta previa and PAS between November 1, 2007, and March 1, 2020, were identified by searching the hospital's electronic database. Demographics, clinical characteristics, intraoperative and postoperative parameters, and outcomes were extracted from the medical records. Women with gynecological malignancies or uterine atony were excluded. Ethical approval was obtained from the Unit of Biomedical Ethics at the Faculty of Medicine at King Abdulaziz University (Number 757-19) in accordance with the Declaration of Helsinki. Because of the type of the study, patient informed consent to review the medical records was not required by King Abdulaziz University Hospital IRB, patient data confidentiality was kept.

Our hospital is a "level III" (subspecialty) center as defined by the American College of Obstetricians and Gynecologists (ACOG) and the Society for Maternal-Fetal Medicine, ${ }^{7}$ and a "specialist center" according to the International Society for Abnormally Invasive Placenta (IS-AIP) criteria for PAS. ${ }^{8}$ The diagnosis of placenta previa was made when the placental edge overlapped or is within $2 \mathrm{~cm}$ of the internal cervical orifice. ${ }^{9}$ The diagnosis of PAS was first made by antenatal trans-abdominal ultrasound and was confirmed clinically intraoperatively, and by histopathology. ${ }^{8,10}$ Our antenatal management includes; admission to hospital from the time of diagnosis till delivery, preoperative consultation, and prospective planning for maternal and neonatal care by the multidisciplinary team, maintaining hemoglobin level above 10.5 $\mathrm{g} / \mathrm{dL}$, giving antenatal corticosteroids for fetal maturity before 34 weeks of gestation, and delivery after 34 weeks of gestation. The decision for damage control surgery was made in near-miss cases by senior obstetrician-gynecologists who had special interest and experience in placenta previa and PAS and were present physically in the operating room.

Abdomino-pelvic packing with laparotomy gauze sponges $(30 \times 30 \mathrm{~cm})$ was performed as described previously ${ }^{11}$ when all other techniques such as suturing placental site, uterine artery ligation, uterine packing, internal iliac artery embolization, and hysterectomy failed. The number of sponges ranged from 2 to 8 (median 4; IQR $2,5.5)$. The sponges were packed firmly over the bleeding raw surfaces in the pelvis, and drains were placed. Broadspectrum antibiotics were given to all cases. The abdomen was closed in the usual manner. Packs were removed via laparotomy after $1(n=2)$ to $2(n=5)$ days when hemostasis was confirmed. The women were transferred to the ICU postoperatively.

\section{Results}

Seven women met the inclusion criteria. Six women were at 34 to 37 weeks gestation, and one woman was at 20 weeks gestation (Table 1). Three women had four previous cesarean sections, three women had three previous cesarean sections, and one woman had two previous cesarean sections. There were three women with placenta previa, three women with placenta previa accreta, and one woman with placenta accreta. Four women did not receive any antenatal care (unregistered) in our hospital, and three women were seen only once in the antenatal care clinics. Three women were admitted 1 day before or on the day of the surgery. Three women underwent an emergency cesarean section. Despite counseling about the risks of conservative management, six women requested to keep the uterus. They consented to cesarean delivery, with possible hysterectomy only if required.

The abdominal incision was a Pfannenstiel incision in six women and a midline vertical incision in one woman (case 4). The incision in the uterus was a low transverse incision in four women (cases 1,2,3, and 5), and in three women, it was in the upper uterine segment. The single case of emergency hysterectomy was for severe vaginal bleeding at 20 weeks gestation in a woman with four previous cesarean sections (case 4) and placenta accreta. Intraoperative findings were suggestive of PAS. During dissection of the urinary bladder, a rent was created, and severe bleeding occurred. One woman had a cesarean hysterectomy (case 1) after pre-cesarean prophylactic balloon catheters insertion, and internal iliac embolization failed to control the bleeding from placenta previa accreta. Bilateral uterine artery ligation and uterine packing with two laparotomy gauze sponges $(30 \times 30 \mathrm{~cm})$ (case 7) failed to prevent primary PPH and hysterectomy.

Estimated "near-miss" intraoperative bleeding ranged from 2 to 7 liters for the seven women (median $5 \mathrm{~L}$; IQR $3.5,6$ ), which was managed by massive blood transfusion. 
Table I Maternal Characteristics and Outcomes

\begin{tabular}{|c|c|c|c|c|c|c|c|c|c|}
\hline Age & $\begin{array}{l}\text { Previous } \\
\text { CS }\end{array}$ & GA & $\begin{array}{l}\text { Ante-Natal Care and } \\
\text { Admission }\end{array}$ & $\begin{array}{l}\text { Preoperative } \\
\text { Diagnosis }\end{array}$ & $\begin{array}{l}\text { Intraoperative } \\
\text { Diagnosis }\end{array}$ & Pathology & Operative Procedures & $\begin{array}{l}\text { Pack } \\
\text { Removal }\end{array}$ & Complications \\
\hline 39 & 4 & 36 & $\begin{array}{l}\text { I Ante-natal visit at } 32 \\
\text { weeks, and was admitted } \\
\text { I week before operation }\end{array}$ & $\begin{array}{l}\text { Placenta previa } \\
\text { accreta by US } \\
\text { outside + MRI in } \\
\text { our hospital }\end{array}$ & $\begin{array}{l}\text { Placenta previa } \\
\text { accreta }\end{array}$ & Accreta & $\begin{array}{l}\text { Precesarean balloon catheters insertion, } \\
\text { elective low transverse CS, internal iliac } \\
\text { embolization, hysterectomy, and packing }\end{array}$ & $\begin{array}{l}\text { After } \\
\text { I day }\end{array}$ & $\begin{array}{l}\text { Disseminated intravascular } \\
\text { coagulation }\end{array}$ \\
\hline 37 & 3 & 37 & $\begin{array}{l}\text { No ante-natal care, and } \\
\text { was admitted I month } \\
\text { before operation }\end{array}$ & $\begin{array}{l}\text { Placenta previa } \\
\text { by US }\end{array}$ & Placenta previa & No accreta & $\begin{array}{l}\text { Elective low transverse CS, followed by } \\
\text { laparotomy for primary PPH, hysterectomy, } \\
\text { and packing }\end{array}$ & $\begin{array}{l}\text { After } \\
\text { I day }\end{array}$ & $\begin{array}{l}\text { Intestinal obstruction } \\
\text { treated by laparotomy for } \\
\text { release of adhesions }\end{array}$ \\
\hline 31 & 3 & 36 & $\begin{array}{l}\text { I Ante-natal visit at } 33 \\
\text { weeks, and was admitted } \\
\text { from ER I day before } \\
\text { operation }\end{array}$ & $\begin{array}{l}\text { Placenta previa } \\
\text { by US }\end{array}$ & Accreta & Accreta & $\begin{array}{l}\text { Elective low transverse CS, followed by } \\
\text { laparotomy for primary PPH, hysterectomy, } \\
\text { and packing }\end{array}$ & $\begin{array}{l}\text { After } 2 \\
\text { days }\end{array}$ & $\begin{array}{l}\text { Disseminated intravascular } \\
\text { coagulation }\end{array}$ \\
\hline 36 & 4 & 20 & $\begin{array}{l}\text { No ante-natal care, and } \\
\text { was admitted from ER } \\
\text { I I days before operation }\end{array}$ & $\begin{array}{l}\text { Placenta accreta } \\
\text { by US }\end{array}$ & Accreta & Accreta & Emergency hysterectomy and packing & $\begin{array}{l}\text { After } 2 \\
\text { days }\end{array}$ & $\begin{array}{l}\text { Vesicovaginal fistula which } \\
\text { was repaired abdominally } \\
5 \text { months later }\end{array}$ \\
\hline 33 & 3 & 37 & $\begin{array}{l}\text { No ante-natal care } \\
\text { admitted } 22 \text { days before } \\
\text { operation }\end{array}$ & $\begin{array}{l}\text { Placenta previa } \\
\text { by US }\end{array}$ & Placenta previa & No accreta & $\begin{array}{l}\text { Elective low transverse CS, followed by } \\
\text { laparotomy for primary PPH, hysterectomy, } \\
\text { and packing }\end{array}$ & $\begin{array}{l}\text { After } 2 \\
\text { days }\end{array}$ & \\
\hline 40 & 4 & 34 & $\begin{array}{l}\text { I Ante-natal visit at } 23 \\
\text { weeks, and was admitted } \\
\text { from ER on the same } \\
\text { operation day }\end{array}$ & $\begin{array}{l}\text { Placenta previa } \\
\text { accrete by US }\end{array}$ & $\begin{array}{l}\text { Placenta previa } \\
\text { accreta }\end{array}$ & Accreta & $\begin{array}{l}\text { Emergency upper uterine segment CS, } \\
\text { followed by laparotomy for primary PPH, } \\
\text { hysterectomy, and packing }\end{array}$ & $\begin{array}{l}\text { After } 2 \\
\text { days }\end{array}$ & $\begin{array}{l}\text { Disseminated intravascular } \\
\text { coagulation, acute kidney } \\
\text { failure requiring dialysis, } \\
\text { and wound infection }\end{array}$ \\
\hline 32 & 2 & 37 & $\begin{array}{l}\text { No ante-natal care and } \\
\text { was admitted from ER in } \\
\text { labor on the same } \\
\text { operation day }\end{array}$ & $\begin{array}{l}\text { Placenta previa } \\
\text { by US }\end{array}$ & Placenta previa & No accreta & $\begin{array}{l}\text { Emergency upper uterine segment CS, } \\
\text { bilateral uterine artery ligation, and uterine } \\
\text { packing, followed by laparotomy for primary } \\
\text { PPH, hysterectomy, and packing }\end{array}$ & $\begin{array}{l}\text { After } 2 \\
\text { days }\end{array}$ & \\
\hline
\end{tabular}


The number of units of transfused packed red blood cells, platelets, and fresh frozen plasma were (median 10; IQR 7.14), (median 6; IQR 6, 12), and (median 6; IQR 6, 12), respectively. Hemostatic agents were applied directly to the bleeding tissue in four cases $(4,5,6$, and 7$)$. One woman was discharged from the ICU on the day of pack removal, three women were discharged from the ICU the day after the pack removal, and three women remained in the ICU after the pack removal for 5, 7, and 17 days. Hospital stays ranged from 8 to 44 days (median 37; IQR 21, 39), after which patients were discharged home. Two women had disseminated intravascular coagulation. One woman developed intestinal obstruction, which was treated by laparotomy for the release of adhesions. A vesicovaginal fistula was successfully repaired abdominally after 5 months. One woman had acute renal failure and wound infection.

\section{Discussion}

The recommended management of placenta previa is the cesarean section with early recourse to hysterectomy when conservative medical and surgical interventions prove ineffective. ${ }^{9,12}$ Cesarean hysterectomy through a vertical incision with the placenta left in situ after delivery of the fetus is currently considered the best management for women with PAS. ${ }^{8}$ Our society is reluctant to provide consent for the cesarean hysterectomy; accordingly, intraoperative measures during cesarean delivery attempt to preserve the uterus. However, complications are common, particularly in multiparous women with a history of multiple cesarean deliveries. This setting further exemplifies the need for managing near-miss events with damage control surgery, with its concomitant burden on the patient as well as resource use.

Abdominopelvic packing has become a valuable strategy for damage control in women with postpartum hemorrhage associated with cesarean delivery and hysterectomy. ${ }^{13-16}$ The American College of Obstetricians and Gynecologists (ACOG) and the Society for MaternalFetal Medicine guidelines note that packing can help achieve patient stabilization and product replacement in the setting of acute uncontrolled hemorrhage. ${ }^{7}$ It should be used as a last resort, in view of the possible complications that may follow it. Although several packing materials have been used for pelvic tamponade, ${ }^{8}$ 2-8 (mean 4.1; IQR 2, 5.5) packs of laparotomy gauze sponges achieved hemostasis in our patients. In general, 24 hours is adequate to achieve optimal clotting and hemostasis. If the packing has controlled bleeding by that time, it generally is removed. ${ }^{13}$ If the packing is removed after less than 24 hours, bleeding will resume, and the risk for pelvic infection or abscess is increased if the packs are left in place for over 72 hours. Although the optimal time to remove packs used for general surgery cases has been suggested as between days 2 and 3 postoperatively, ${ }^{6}$ packs were removed after $24-48$ hours in our patients. We wished to avoid the risk of further complications, and hemostasis had been achieved.

There is paucity of reports on packing used in cases of uncontrolled bleeding associated with PAS. For example, a UK hospital cohort of seven patients who underwent abdominopelvic packing for intractable postpartum bleeding over a 9-year period included two with PAS. ${ }^{14}$ A French questionnaire study included 25 participating centers who submitted data on their experience with 53 cases of abdominal packing for PPH, comprising one through 7 cases at each center over a 10-year period. ${ }^{17}$ Hemorrhage was associated with PAS in 12 cases. Laparotomy pads were used in $85 \%$ of the cases. Bleeding control was unsuccessful in 20 (38\%) women, with continuing hemorrhage treated by a second surgical intervention $(n=6)$, pelvic artery embolization $(n=6)$, and further intensive resuscitation and medicinal therapy $(n=8)$. The mortality rate was $24 \%$. These observations support that additional data are needed on damage control surgery in cases of PAS with PPH.

Disadvantages of abdominopelvic packing, in addition to the need for a second procedure to remove the pack, include the possibility that continued bleeding may avoid diagnosis in a setting without a drainage channel and the risk of complications including compartmental syndrome and sepsis. None of the patients in our small sample died, and all were discharged after 8 to 44 days of hospitalization. The authors of the 53 patient multicenter case series suggested that delays in hysterectomy and surgeon inexperience may have contributed to their high $24 \%$ mortality rate. ${ }^{17}$ Two of three deaths reported in a series of 66 women who underwent an emergency peripartum hysterectomy in a single center in Saudi Arabia were theorized to be related to delays in hysterectomy. ${ }^{18}$

Our study is limited by its small size and retrospective design. It intends to report the outcomes of damage control surgery in women who may experience life-threatening near-miss hemorrhage for placenta previa and PAS in a culture of hysterectomy resistance.

\section{Conclusion}

Damage control surgery can be life-saving. It should be in the armamentarium of the health care providers managing 
women with placenta previa, and placenta accreta spectrum.

\section{Acknowledgments}

This project was funded by the Deanship of Scientific Research (DSR) at King Abdulaziz University, Jeddah, Saudi Arabia, under Grant Number 005/428. The authors, therefore, acknowledge, with thanks, DSR technical and financial support.

\section{Disclosure}

The authors report no conflicts of interest for this work.

\section{References}

1. World Health Organization. Maternal mortality. Available from: https://www.who.int/news-room/fact-sheets/detail/maternal-mortality. Accessed November 1, 2021.

2. Committee on Practice Bulletins-Obstetrics. Practice bulletin No.183. Postpartum hemorrhage. Obstet Gynecol. 2017;130(4):e168-e186. doi:10.1097/AOG.0000000000002351

3. Marocchini M, Lauféron J, Quantin C, Sagot P. Postpartum hemorrhage with transfusion: trends, near misses, risk factors and management at the scale of a perinatal network. J Gynecol Obstet Hum Reprod. 2017;46(5):455-460.

4. Maswime S, Buchmann E. A systematic review of maternal near-miss and mortality due to postpartum hemorrhage. Int J Gynaecol Obstet. 2017;137:1-7. doi:10.1002/ijgo.12096

5. Say L, Souza JP, Pattinson RC; for the WHO working group on Maternal Mortality and Morbidity classifications. Maternal near miss-towards a standard tool for monitoring quality of maternal health care. Best Pract Res Clin Obstet Gynecol. 2009;23:287-296. doi:10.1016/j.bpobgyn.2009.01.007

6. Pacheco LD, Lozada MJ, Saade GR, Hankins GDV. Damage-control surgery for obstetric hemorrhage. Obstet Gynecol. 2018;132:423-427. doi:10.1097/AOG.0000000000002743

7. American College of Obstetricians and Gynecologists, Society for Maternal-Fetal Medicine. Obstetric care consensus No. 7 Summary: placenta accreta spectrum. Obstet Gynecol. 2018;132:e259-e275. doi:10.1097/AOG.0000000000002983
8. Collins SL, Alemdar B, van Beekhuizen HJ, et al. Evidence-based guidelines for the management of abnormally invasive placenta: recommendations from the International Society for Abnormally Invasive Placenta. Am J Obstet Gynecol. 2019;220:511-526. doi:10.1016/j.ajog.2019.02.054

9. D'Antonio F, Bhide A. Ultrasound in placental disorders. Best Pract Res Clin Obstet Gynaecol. 2014;28:429-442. doi:10.1016/j. bpobgyn.2014.01.001

10. Jauniaux E, Bhide A. Prenatal ultrasound diagnosis and outcome of placenta previa accreta after cesarean delivery: a systematic review and meta-analysis. Am J Obstet Gynecol. 2017;217:27-36. doi:10.1016/j.ajog.2017.02.050

11. Ghourab S, Al-Nuaim L, Al-Jabari A, et al. Abdominopelvic packing to control severe hemorrhage following cesarean hysterectomy. J Obstet Gynecol. 1999;19:155-158. doi:10.1080/01443619965480

12. Jauniaux E, Alfirevic Z, Bhide AG, et al. Placenta previa and placenta accreta: diagnosis and management: green-top Guideline No. 27a. BJOG. 2019;126(1):e1-e48. doi:10.1111/1471-0528.15306

13. Belfort MA. Postpartum hemorrhage management approaches requiring laparotomy. Available from: https://www.uptodate.com/contents/ postpartum-hemorrhage-management-approaches-requiringlaparotomy. Accessed July 18, 2020.

14. Yoong W, Lavina A, Ali A, Sivashanmugarajan V, Govind A, McMonagle M. Abdomino-pelvic packing revisited: an often forgotten technique for managing intractable venous obstetric hemorrhage. Aust N Z J Obstet Gynaecol. 2019;59:201-207. doi:10.1111/ajo.12909

15. Touhami O, Marzouk SB, Kehila M, et al. Efficacy and safety of pelvic packing after emergency peripartum hysterectomy (EPH) in postpartum hemorrhage (PPH) setting. Eur J Obstet Gynecol Reprod Biol. 2016;202:32-35. doi:10.1016/j.ejogrb.2016.04.013

16. Yoong W, Sivashanmugarajan V, McMonagle M, Hamilton J, Karoshi M, Lodhi W. Pelvic and vaginal packing for intractable venous obstetric hemorrhage: practical tips for the obstetrician. Obstet Gynecol. 2014;16:276-280. doi:10.1111/tog.12129

17. Deffieux X, Vinchant M, Wigniolle I, Goffinet F, Sentilhes L. Maternal outcome after abdominal packing for uncontrolled postpartum hemorrhage despite peripartum hysterectomy. PLoS One. 2017;12:e0177092. doi:10.1371/journal.pone.0177092

18. Begum M, Alsafi F, ElFarra J, Tamim HM, Le T. Emergency peripartum hysterectomy in a tertiary care hospital in Saudi Arabia. J Obstet Gynecol India. 2014;64:321-327. doi:10.1007/s13224-013-0423-1
International Journal of Women's Health

\section{Publish your work in this journal}

The International Journal of Women's Health is an international, peerreviewed open-access journal publishing original research, reports, editorials, reviews and commentaries on all aspects of women's healthcare including gynecology, obstetrics, and breast cancer. The manuscript management system is completely online and includes a very quick and fair peer-review system, which is all easy to use. Visit http://www.dovepress.com/testimonials.php to read real quotes from published authors. 